УДК 811.111

DOI: $10.15421 / 3820010$

O. Pakhomova

О. В. Пахомова

Е. В. Пахомова

Oles Honchar Dnipropetrovsk National University

Дніпровський національний університет імені Олеся Гончара

Днепровский нащиональный университет имени Олеся Гончара

\title{
THE STUDY ON GROUP WORK IMPLEMENTATION IN TEFL BY UKRAINIAN SCHOOL TEACHERS
}

\section{ДОСЛІДЖЕННЯ ВИКОРИСТАННЯ ГРУПОВОЇ РОБОТИ ПРИ НАВЧАННІ АНГЛІЙСЬКОЇ МОВОЮ УКРАЇНСЬКИМИ ВЧИТЕЛЯМИ}

\author{
ИССЛЕДОВАНИЕ ИСПОЛЬЗОВАНИЯ ГРУППОВОЙ РАБОТЫ \\ ПРИ ОБУЧЕНИИ АНГЛИЙСКОМУ ЯЗЫКУ УКРАИНСКИМИ \\ УЧИТЕЛЯМИ
}

The article reviles the potential of group work as an effective means for mastering EFL. This article aims to outline the definition of group work as methods of teaching notion, to analyze the advantages of group work for learners and teachers on theoretical level and to contrast them with the results of the practical research on the group work experience in Ukrainian school. The basic definition of group work is students working together with a number of other students rather in pairs or as a whole class. Numerous authors emphasize the advantages of group work as it makes learning more meaningful, namely, increase the time and opportunity to use the language and learners motivation; it provides positive affective climate and encourages a friendly relaxed learning environment. Despite the majority of theoretical works on the benefits and effectiveness of group work for EFL acquisition, our research reviles that teachers who work in Ukrainian schools still tend to implement traditional forms of whole class and individual work interaction types instead of group work. The received results logically prove that the prevailing number of teachers $(63,5 \%)$ of any experience level see no real benefits in harnessing group work in classroom interaction. They note more disadvantages than advantages in group work, such as noise and fall of discipline, difficulty in controlling and assessing the individual participation in the group work performance, difficulties in organizing and grouping learners. Altogether, the teachers tackle with the lack of methodology knowledge on group work and experience due to the teacher-oriented approach dominating in teacher training higher schools in Ukraine.

Keywords: group work, EFL acquisition, interaction hypothesis, interaction, classroom management.

Розглянуто потенціал групової роботи як ефективного засобу для оволодіння англійською мовою. У статті масмо на меті окреслити різні визначення групової роботи як методичного поняття, проаналізувати переваги групової роботи для учнів та вчителів на теоретичному рівні та порівняти їх 3 результатами практичних досліджень досвіду групової роботи в українській школі. Основне визначення групової роботи - це форма роботи у класі, при якій учні працюють разом 3 низкою інших учнів, а не в парах або цілим класом. Численні автори підкреслюють переваги групової роботи, оскільки вона робить навчання більш осмисленим, а саме - збільшус час та можливість використовувати мову та мотивус учнів; вона забезпечус позитивний психологічний клімат та створюс доброзичливе невимушене навчальне середовище. Незважаючи на великий теоретичний доробок про переваги та ефективність використання групової роботи у процесі навчання англійської мови, наше дослідження виявило, що вчителі, які працюють в українських школах, як правило, впроваджують традиційні форми фронтальної та індивідуальної роботи замість групової роботи. Отримані результати логічно підтвер-

(C) Pakhomova O., 2020 
джують, що переважна кількість вчителів (63,5\%) будь-якого рівня досвіду, які взяли участь у дослідженні, не бачить реальної користі у використанні групової роботи у класі. Вони відзначають більше недоліків, ніж переваг у груповій роботі, таких як шум і падіння дисципліни, труднощі в контролі та оцінці індивідуальної участі учнів у груповій роботі, труднощі в організації та групуванні учнів. Загалом учителі стикаються 3 нестачею методологічних знань щодо організації групової роботи через підхід, оріснтований на вчителя, а не на учнів, що домінус у вищих навчальних закладах України.

Ключові слова: групові форми роботи, оволодіння англійською мовою, гіпотеза взаємодії, види класної взаємодії.

Раскрыт потенциал групповой работы как эффективного средства овладения английским языком. Целью данной статьи является дать определение групповой работе как методическому понятию, проанализировать преимущества групповой работы для учащихся и преподавателей на теоретическом уровне и сопоставить их с результатами практического исследования опыта использования групповой работы в украинской школе. Основное определение групповой работы - это форма классной работы, при которой учащиеся работают вместе в группах, а не в парах или фронтально. Многочисленные авторы подчеркивают преимущества групповой работы, так как она делает обучение более значимым, а именно - увеличивает время и возможность использовать язык и мотивирует учащихся на его изучение; она обеспечивает положительный аффективный климат и способствует созданию благоприятной учебной среды. Несмотря на множество теоретических работ о преимуществах и эффективности групповой работы при обучении английскому языку, наше исследование обнаружило, что учителя, которые работают в украинских школах, все еще склонны применять традиционные формы фронтальной и индивидуальной работы в классе вместо групповой работы. Полученные результаты логически доказывают, что преобладающее количество учителей $(63,5 \%)$ любого уровня опыта не видят реальных преимуществ в использовании групповой работы в классе. Они отмечают больше недостатков, чем преимуществ применения групповой работы, таких как шум и падение дисциплины, сложность контроля и оценки индивидуального участия в выполнении групповой работы, трудности в организации и группировании учащихся. В целом учителя сталкиваются с недостатком методических знаний по групповой работе и опытом из-за подхода, ориентированного на учителя, доминирующего в педагогических вузах в Украине.

Ключевые слова: групповая работа, овладение английским языком, гипотеза взаимодействия, виды классного взаимодействия.

Learning from other people is one of the most natural ways of learning known from the early age of mankind. Among other learning contexts group learning proves to be the most efficient and beneficial as well as instinctive. Nowadays when the key skills such as communication skills, problem-solving skills, collaborative skills are demanded for successful career and social life, they can not be learnt solely but only with and from other people.

Much of the modern scientific articles and literature on the theory and practice of education and teaching English methods claim the group work to be important and useful. Yet they focus on creating up-to-date different learning environments such as augmented reality, or using variety of learning resources, for example computer applications and cloud technologies. Moreover, the majority of secondary, high and higher education schools continue pursuing traditional forms of training as those that proved their effectiveness and predictability of results.

So, the potential of group work as an effective means for mastering EFL has been somewhat neglected in recent years. This article aims to outline the definition of group work as methods of teaching notion, to analyze the advantages of group work for learners and teachers on theoretical level and to contrast them with the results of the practical research on the group work experience in Ukrainian school. 
Analysis of research and publications discovers that the scientific grounds for group work usage lie in the Krashen's (1982) comprehensible - input [4], Swain's (1993) comprehensible - output hypotheses [10], and Long's (1985) interaction hypothesis [6]. Krashen and Swain provide the psycholinguistic rationale for group work. On the results of their research, they conclude that group work provides contexts for meaningful negotiation between the learners, and an environment in which learners can comprehend, and produce their own speech $[4 ; 10]$.

According to the interaction hypothesis language acquisition requires or greatly benefits from interaction, communication and especially negotiation of meaning, which happens when interlocutors attempt to overcome problems in conveying their meaning, resulting in both additional input and useful feedback on the learner's own production [8, p. 263]. Interaction hypothesis exists in two forms both of them emphasize the learning opportunities and language development created via interaction in group form.

In the following years M. Long, P. Porter, D. Jaques, Ph. Chappel, Cl. Kramsch, J. Scrivener, J. Harmer, Ph. Race and the others study the potential of group work in different aspects.

The statement of the main research material. The researchers of the group work issue give the variety of the definitions of the notion studied. The basic definition of group work is «students working together with a number of other students rather in pairs or as a whole class» [10, p.401]. Scott Thornbury (2006) defines group work as a form of classroom interaction where learners work together, part or all of the time, in small groups [12, p. 95]. J. Harmer (2001) defines group work as a cooperative activity, perhaps of five people [2].

Jack C. Richards and Richard Schmidt (2011) consider group work a learning activity which involves a small group of learners working together. The group may work on a single task, or on different parts of a larger task [8, p. 234].

According to Brown, (2001) group work is a generic term covering a multiplicity of techniques in which two or more students are assigned a task that involves collaboration and self initiated language. It implies small group work, that is, students in groups of perhaps six or fewer [1, p.177]. The author also analyses the advantages and disadvantages of group work for ESL acquisition.

Phill Race (2000) explores group work as involving two main kinds of processes: learning processes and working together. He also points out that group work implies helping learners in groups to learn by doing, learn through feedback and learn from their mistakes. Ph. Race emphasizes the role and level of learners' motivation arisen from successful group learning [9].

Altogether, group work as a means of EFL learning implies the following characteristics:

- collaboration aiming to fulfill the common learning task,

- the small size of a group (from three to six learners, ideally five),

- interaction exploiting the target language,

- oral performance as an essence of communicative task and a feedback.

Numerous authors emphasize the advantages of group work as it makes learning more meaningful, namely, increase the time and opportunity to use the language and learners motivation (Long and Porter (1985); provides positive affective climate (Harmer (2001) and encourages a friendly relaxed learning environment (Scrivener 2011). 
Long and Porter (1985) claim the validity for group work on pedagogical and psychological grounds. They point out that group work elevates the quality of learners oral performance due to friendly atmosphere in the group of peers [6].

We analyze the advantages of group work from two angles: pluses for teachers and for learners. The analysis results are presented in the table 1 .

\section{The benefits of group work for learners and teachers}

\begin{tabular}{|c|c|}
\hline Group work Benefits for Learners & Group work Benefits for Teachers \\
\hline $\begin{array}{l}\text { Learners practice the language they are } \\
\text { trying to learn and use it productively and } \\
\text { creatively }\end{array}$ & $\begin{array}{l}\text { It allows authentic performance for } \\
\text { assessments: pronunciation, spoken } \\
\text { grammar, and ability to communicate just } \\
\text { by listening in on some classroom group } \\
\text { work }\end{array}$ \\
\hline $\begin{array}{l}\text { Learners challenge, encourage and help } \\
\text { each other: less accomplished learners will } \\
\text { become better speakers just by talking to }\end{array}$ & $\begin{array}{l}\text { It improves the quality of learners talk by } \\
\text { stimulating to use target language in more } \\
\text { complex way faster and }\end{array}$ \\
\hline $\begin{array}{l}\text { others more advanced, receive social } \\
\text { support and encouragement to take risks, } \\
\text { refine understanding through discussion } \\
\text { and explanation }\end{array}$ & $\begin{array}{l}\text { spontaneously. It trains fluency over } \\
\text { accuracy }\end{array}$ \\
\hline $\begin{array}{l}\text { It activates different learning styles, e.g. } \\
\text { social or interpersonal. Learners who learn } \\
\text { this way work well with others and benefit } \\
\text { from working things out with groups. } \\
\text { Learners can also choose their level of } \\
\text { participation }\end{array}$ & $\begin{array}{l}\text { It allows greater potential for the } \\
\text { individualization of instructions }\end{array}$ \\
\hline $\begin{array}{l}\text { It reinforces meta cognitive skills that } \\
\text { are relevant to both group and individual } \\
\text { work: break complex tasks into parts and } \\
\text { steps, plan and manage time, challenge } \\
\text { assumptions }\end{array}$ & $\begin{array}{l}\text { It saves instructor's efforts: teachers should } \\
\text { take care to assign group work tasks that } \\
\text { truly fulfill the learning objectives of the } \\
\text { course and lend } \\
\text { themselves to collaboration }\end{array}$ \\
\hline $\begin{array}{l}\text { Learners develop skills specific to } \\
\text { collaborative efforts: tackle more complex } \\
\text { problems than they could on their own, take } \\
\text { and delegate roles and responsibilities, find } \\
\text { effective peers to emulate }\end{array}$ & $\begin{array}{l}\text { It can be refreshing for instructors as group } \\
\text { work introduces more unpredictability in } \\
\text { teaching. } \\
\text { Organizing it can simulate teacher } \\
\text { selfdevelopment }\end{array}$ \\
\hline $\begin{array}{l}\text { It provides autonomy form the teacher by } \\
\text { allowing learners make their own decisions } \\
\text { and adopt different communicative roles }\end{array}$ & $\begin{array}{l}\text { It encourages active learning, shifts the focus } \\
\text { from teacher-oriented } \\
\text { learning to student-oriented learning }\end{array}$ \\
\hline $\begin{array}{l}\text { Personal relationship are usually less } \\
\text { problematic in a group of five rather then } \\
\text { in pairs }\end{array}$ & $\begin{array}{l}\text { Group work provide environment for } \\
\text { mastering take -turning mechanism }\end{array}$ \\
\hline $\begin{array}{l}\text { Group work provides wider feedback } \\
\text { on the performance from the peers and a } \\
\text { teacher }\end{array}$ & $\begin{array}{l}\text { Group work saves the time and can reduce } \\
\text { the number of final products a teacher has } \\
\text { to grade }\end{array}$ \\
\hline
\end{tabular}


Yet, despite the majority of theoretical works on the benefits and effectiveness of group work for EFL acquisition, our research reviles that teachers who work in Ukrainian schools still opt for traditional forms of whole class and individual work interaction types.

The practical research on the application of group work by Ukrainian school teachers of English was held at the Department of Post-graduate education of Kryvyi Rih pedagogical university from 2016 till 2019. The sample size was approximately 200 secondary and high school English teachers and ranged from novice teachers with no more than 2 years of teaching experience to qualified teachers of first and second levels of qualification.

The research aimed to explore: the teachers' awareness of benefits and pitfalls of group work, the frequency and variability of group work they apply on the daily basis. The study took place in two phases: a questionnaire and a field observation. The questionnaire inquires: 1) the frequency of group work use in ESL classroom; 2) the variability of group work applied; 3 ) the awareness of benefits and pitfalls of group work.

Generally, the survey detects that $9,74 \%$ of respondents asked never use group work in their classrooms, $61,05 \%$ use it occasionally $1-2$ times a week, 19,39\% apply group work 3-5 times a week, only $9,82 \%$ of respondents use group work regularly almost every class.

The study of variability of group work demonstrates that the majority of the respondents $(53,79 \%)$ names $2-3$ types of group work among which they mention: making up dialogues in pairs, role plays, and project work. The minority $(6,5 \%)$ enumerate from 7 to 10 types of group work, and 39,71\% of teachers questioned know 4-6 group work types.

The received results logically prove that the prevailing number of teachers $(63,5 \%)$ of any experience level see no real benefits in harnessing group work in classroom interaction. They note more disadvantages than advantages in group work, such as noise and fall of discipline, difficulty in controlling and assessing the individual participation in the group work performance, difficulties in organizing and grouping learners. The results received are presented in the table 2.

Table 2

The results of the practical research on the application of group work by Ukrainian school teachers of English

\begin{tabular}{|l|c|c|c|c|c|c|c|c|c|}
\hline \multirow{2}{*}{$\begin{array}{l}\text { Cxiteria } \\
\text { Experience } \\
\text { Level of respondents }\end{array}$} & \multicolumn{4}{c|}{ Frequency (\%) } & \multicolumn{3}{c|}{$\begin{array}{c}\text { Benefit } \\
\text { awareness (\%) }\end{array}$} & \multicolumn{2}{c|}{ Variability (\%) } \\
\cline { 2 - 11 } & never & $\begin{array}{c}1-2 \\
\text { times/ } \\
\text { week }\end{array}$ & $\begin{array}{c}3-5 \\
\text { times/ } \\
\text { week }\end{array}$ & $\begin{array}{c}\text { Every } \\
\text { class }\end{array}$ & $\begin{array}{c}\text { Advan } \\
\text { tages }\end{array}$ & $\begin{array}{c}\text { Disadvan } \\
\text { tages }\end{array}$ & $\begin{array}{c}2-3 \\
\text { types }\end{array}$ & $\begin{array}{c}4-6 \\
\text { types }\end{array}$ & $\begin{array}{c}7-10 \\
\text { types }\end{array}$ \\
\hline Novice teachers & 12,72 & 63,41 & 15,27 & 8,6 & 32,74 & 67,26 & 59,82 & 40,18 & 0 \\
\hline First qualification level & 8,51 & 61,38 & 20,64 & 9,47 & 35,28 & 64,72 & 52,62 & 38,43 & 8,95 \\
\hline Second qualification level & 7,96 & 58,37 & 22,27 & 11,4 & 41,48 & 58,52 & 48,93 & 40,52 & 10,55 \\
\hline Total & 9,74 & 61,05 & 19,39 & 9,82 & 36,5 & 63,5 & 53,79 & 39,71 & 6,5 \\
\hline
\end{tabular}

The analysis of the classroom observations proves the results of the questionnaire and reviles the real reasons of low group work benefit awareness among Ukrainian school teachers. Altogether, the teachers tackle with the lack of methodology knowledge on group work and experience due to the teacher-oriented approach dominating in teacher training higher schools in Ukraine. 
Thus, the number of problems and pitfalls complained by teachers can be divided into two parts: psychological and organizational ones. Psychological difficulties include: learners are not listening to fellow group members; learners talks too much or dominates the group; learner talks too little or is «freeloading»; not all learners enjoy working in a group, they want to be the teacher focus of attention; there is tension among group member or unfriendly relation; learners are disruptive or disobedient.

Another group of hardships include difficulties in lesson planning and classroom management. Teachers claim that: learners are not on task or are chatting inappropriately; learners use native language not English; some learners are resistant to group work because they do not accustomed to it; group work takes more time to organize, especially with learners moving around the class; it can be chaotic; some teachers complain they loose the feel and control of the class; some teachers do not know how to fit group work into lesson sequence; some teachers claim group work lacks of correction of mistakes.

Conclusion. Group work can be an effective method to motivate students, encourage active learning, and develop key critical-thinking, communication, and decision-making skills, and bridge the gap between input and output. Many problems associated with inclass group work can be prevented with careful preparation, specific instructions, and appropriate facilitation. Despite the great attention of researches to the theoretical basis of group work, our research reveals that teachers who work in Ukrainian schools still tend to use traditional forms of whole class and individual work interaction types in their teaching practice and fail to see the benefits of group work. This occurs due to the lack of methodology knowledge on group work.

\section{References}

1. Brown, D. (2001). Teaching by Principles: an 7. Long, M. (1996). The role of the linguistic interactive approach to language pedagogy. New York: Addison Wesley Longman, Inc.

2. Harmer, J. (2001). The practice of English language teaching. $3^{\text {rd }}$ edition. Pearson Education Limited, Longman, Harlow, 8. United Kingdom, $371 \mathrm{p}$.

3. Jaques, D. (2000). Learning in Groups: A Handbook for Improving Group Work, 3rd ed. London: Kogan Page.

4. Krashen, Stephen D. (1982). Principles and practice in second language acquisition. Oxford: Pergamon. URL: http://www. sdkrashen.com/Principles_and_Practice/ Principles_and_Practice.pdf.

5. Kramsch, Cl. (1992). Interactive discourse in small and large groups. W. Rivers (Ed.), Interactive Language Teaching. New York: Cambridge University Press. $1730 \mathrm{p}$.

6. Long, M., Porter, P. Group (1985). Work, Interlanguage Talk, and Second Language Acquisition. TESOL Quarterly, 19, 207$228 \mathrm{p}$. environment in second language acquisition. Ritchie, W., Bhatia, Tej (eds.). Handbook of second language acquisition. Academic Press, San Diego, 413-468 p.

8. Richards, Jack C., Schmidt Richard (2011). Longman Dictionary of Language teaching and applied linguistics. $4^{\text {th }}$ ed. Routledge, London, $595 \mathrm{p}$.

9. Race, Phil (2000). 5000 tips on group learning. Routledge, London, $148 \mathrm{p}$.

10. Scrivener, J. (2011). Learning teaching. The essential guide to English language teaching. $3^{\text {rd }}$ ed. Macmillan, London, 2011, $414 \mathrm{p}$.

11. Swain, M. (1993). The output hypothesis: Just speaking and writing aren't enough. The Canadian Modern Language Review 50(1). 158-164 p.

12. Thornbury, Scott (2006) An A - Z of ELT. A dictionary of terms and concepts.

13. Macmillans books for teachers. $256 \mathrm{p}$.

Надійшла до редакиії 10.10.2019 